\title{
Influence and impact: interacting factors in asylum policy-making and implementation in Canada and Turkey (1988-92)
}

\author{
Saime Özçürümez (D) and Christina Hamer
}

Department of Political Science and Public Administration, Bilkent University, Ankara, Turkey

\begin{abstract}
With rates of asylum seekers increasing across decades worldwide, why do highand middle-income countries persistently adopt more restrictive asylum policies? By analyzing data from the cases of Canada and Turkey (1988-92), this study shows that domestic policy preferences of decision-makers and refugee determination systems constitute the factors with the highest impact on restrictive asylum policy-making. Through the use of latent content analysis of primary historical documents and elite and expert interviews and an innovative application of the ADVIAN classification method of impact analysis, this study claims that interactions among institutions are critical for the changes a country's asylum policy. Conclusions of this study challenge existing research to move beyond monocausal explanatory schemes for understanding restrictive asylum policy trends and engage with complex frameworks accounting for interacting factors.
\end{abstract}

ARTICLE HISTORY Received 5 July 2018; Accepted 1 November 2018

KEYWORDS ADVIAN classification; asylum policy; Canada; impact analysis; Turkey

\section{Introduction}

The diverse responses of industrialized countries to the 2015 refugee crisis thrust one question into the center of academic, policy-making, media and public debates: what determines asylum policy change? Academics concur that over the last 25 years asylum policies in industrialized countries have become increasingly restrictive while numbers of asylum seekers have grown. ${ }^{1}$ The UNHCR (United Nations High Commissioner of Refugees) 2017 statistics report that only one percent of the world's refugees were offered resettlement in industrialized countries. ${ }^{2}$ Though migration regimes appear to have become more liberal in some countries, close examination reveals that they too have become more selective and restrictive particularly

CONTACT Christina Hamer $\otimes$ christina@bilkent.edu.tr $\Theta$ Department of Political Science and Public Administration, Faculty of Economic, Administrative and Social Sciences, Bilkent University, Ankara 06800, TURKEY

(c) 2018 Informa UK Limited, trading as Taylor \& Francis Group 
favoring highly skilled and employable individuals. ${ }^{3}$ Various scholars have explained why industrialized countries choose the more restrictive asylum policy route by referring to a country's historical experience in general, the international context, ${ }^{4}$ or mass influx of refugees the 1980s, which resulted in a 'backlash' in the 2000s. ${ }^{5}$ Those who focus on the ambiguity of international law on international protection further argue that national politics defines the domestic interpretation of international law for states' practices. ${ }^{6}$ Others propose that both migration policies and asylum policies become more restrictive due to the receiving society's opinions around migration flows and the political rise of the 'radical right'. ${ }^{7}$ Still other researchers present restrictive asylum policies as an austerity measure and as a response to scarcity in economically challenging times. ${ }^{8}$ Then, some caution that this trend could be the result of more than simply a response to 'severe strain'.

The literature discusses border control policies and the 'thickening' of borders as a type of increased restriction in asylum policies. These restrictions have been discussed as a response to the problem of the 'liberal paradox' and the challenge to sovereign borders represented by the human rights of asylum seekers who have entered countries of asylum. Benhabib explains that 'there is a constitutive dilemma in the attempt of modern nation states to justify their legitimacy through recourse to universalist moral principles of human rights which then get particularistically circumscribed'. ${ }^{10}$ The arrival of asylum seekers and their claims to human rights challenge nations' sovereign right to grant or refuse access to their territories. ${ }^{11}$ In response to this challenge, states have developed 'thick borders' through mechanisms such as safe third-country agreements, the Pacific Solution, the European Border and Coast Guard Agency (FRONTEX) and the European Asylum Support Office (EASO) in the European Union (EU), and the Stockholm Program. ${ }^{12}$

Yet, none of these propositions provides a complete explanation as to why all industrialized countries are on a decades long trajectory of gradual and greater asylum policy restriction, particularly considering these countries host only 20 percent of the world's refugees, and that those refugees tend to be applying for reasons of political persecution mostly individually and/or with their dependents, rather than as masses fleeing severe or violent conflict. ${ }^{13}$ In 2015, the attempts by Syrians and others to reach Europe in large numbers unsettled this pattern because most moving toward Europe were passing through safe third-countries and not arriving directly from the area of conflict. European countries immediately aimed to design restrictive policies both individually and collectively by involving the third-country, Turkey, through several new mechanisms, one of which was the EU-Turkey Statement. ${ }^{14}$

This study suggests that greater explanation for the restrictive trajectory of asylum policies might be found in the analysis of institutional factors and interactions among them. This research fills a gap in the literature on 
asylum policy change in three ways. First, the study investigates propositions for explaining restrictive policy change beyond political explanations such as the move of politics to the right in receiving states, economic explanations such as asylum seekers challenging the budgets of host industrialized societies, and the sweeping historical justifications such as past negative experience dealing with large numbers of refugees. This study, alternatively, proposes to use a comparative explanatory framework for the countries examined that accounts for asylum law, refugee determination system, domestic policy preferences of decision-makers, international context, historical experience and local capacity. Second, this study utilizes an impact analysis of data collected through latent content analysis of primary historical documents, published reports and legal documents as well as interviews with policy elites involved in the management of responses to the 1988-92 asylum flows and experts who work on asylum policy in each of the cases. Third, this research compares Turkey and Canada which share asylum policy contexts that present similarities for comparison, however, differ significantly in terms of their trajectory in their approach to refugee status determination and settlement processes. In doing so, this study paves the way for further research into the reasons behind restrictive asylum policy trends for all countries targeted by asylum seekers across the world.

The article continues with a note on case selection and methodology, then analyzes the data from each case country. A discussion follows on comparative findings for Canada and Turkey and concludes with reflections on, as well as implications for, current and future asylum policy processes. Overall, this study finds that for both case countries, the design of a country's refugee determination system is the critical factor in shaping a country's asylum policy response at a given point in time. The design of the refugee determination system is itself highly influenced by domestic policy preferences of decision-makers. In this research, domestic policy preferences of decisionmakers constitute more than the political orientation of the governing party at the time of policy change. This factor is constructed through a combination of dynamics embedded in the country's approach to international protection as well as the existing policy-makers' preferences and the policy tools available for addressing the asylum related challenges. Domestic policy-makers mediate the extent to which historical experience and international context are incorporated into the policy processes and outputs thereby influencing the refugee determination system.

\section{Research design and methodology}

This study relies on a diverse case study design. ${ }^{15}$ Diverse case studies allow for comparative analysis of cases that represent in the minimal sense ... a full variation in [a] population' or set of cases. ${ }^{16}$ Through analysis of cases 
representing the greatest variation, inferences can be made about all the cases in the set. For this study, the set of possible case countries includes those that experience asylum inflows and have the following set of characteristics: industrialized, asylum seeker and refugee hosting, middle to high income, members to a set of international organizations among which are the OECD, NATO, WTO (World Trade Organization), G20, UNHCR, and IOM (International Organization for Migration). Canada and Turkey, as diverse cases from this set, represent 'a full variation' or cases with the greatest differences within this set. Analysis of Canada and Turkey as diverse cases, therefore, has explanatory power over the larger set of case countries represented here.

Canada has been categorized as a country of immigration, ${ }^{17}$ and Turkey has been a country of immigration which experienced different types of flows in the post-1950s. ${ }^{18}$ Turkey is a country of first asylum, facilitating resettlement to third countries, while Canada is a country of resettlement, often resettling refugees who have been under protection in Turkey or other countries of first asylum. Canada is geographically remote with regard to asylum flows, surrounded by three oceans and sharing a land border with only the US. Turkey, on the other hand, shares a land border with five lowand medium-income countries in the Middle East and two more countries in Europe. Migration flows, produced for different reasons, generally move across Turkey from East to West. ${ }^{19}$ Whether resulting in transit flows or en masse temporary refuge, conflicts in countries to the southeast and east of Turkey have resulted in mass asylum flows that have entered Turkey since the 1970 s. $^{20}$

While both Canada and Turkey are signatories to the UN Convention on Refugees and the subsequent 1967 Protocol, Turkey has always maintained a geographical restriction stipulating that it will resettle refugees as defined in the 1951 Convention, as only those escaping conflict in Europe. Yet, Turkey has consistently received people fleeing conflict in their home countries from the east (non-European countries). Therefore, Turkey has shouldered the responsibility of international protection, if not as a country of resettlement then as a country of first asylum, often for months and even years. Canada and Turkey have been recognized by the UNHCR numerous times over the past decade years as among the top 15 refugee hosting industrialized countries.

While the Scandinavian countries, particularly Sweden, could also have been examined as diverse cases compared to Turkey, for the time period being evaluated, Sweden experienced a very high number of asylum applications, approximately equivalent to 2 percent of its population at the time. ${ }^{21}$ Since Turkey represents a country that experienced a mass influx between 1988 and 1992, the case most diverse would need to have experienced less of an influx during those years than Turkey. Therefore, Canada was selected, and not Sweden, as asylum applications to Canada over the 5 
years totaled the equivalent of approximately 0.5 percent of its total population. $^{22}$

With the aim to study asylum seeker and refugee receiving countries on a trajectory of more restrictive asylum policies, this study comparatively analyzes policy responses in Canada and Turkey for the 1988-92 period. Cross-border mobility in general increased toward the end of the 1980s and the beginning of the 1990s. By focusing on this period, the research accounts for the international context created by the fall of the Berlin Wall, the opening of Eastern European countries, beginnings of the Yugoslav Wars and the Gulf Wars among the set of factors to be considered as impacting asylum policy change from the international level. Scholars of asylum policy and data from the interviewees mark this period (1988-92) as a defining period for the study of refugee status determination processes in Turkey for several reasons. The dynamics of refugee status determination policy change became stark with the mass influx from Iraq. In this period, Turkey's asylum policy responded to the international context while pursuing domestic preferences around maintaining the geographical limitation, ensuring national security concerns around who crosses its borders and promoting preferential policies for admitting those with ethnic Turkish identity. ${ }^{23}$ For Canada, 1988-92 was also a defining period in which domestic concerns focused on increasing immigration while countering what was seen as fraudulent or exploitative use of the asylum process. ${ }^{24}$ At the time, Canada was also receiving increasing numbers of asylum applications from people coming through the US. ${ }^{25}$ While immigration levels in the years 1986-90 rose sharply above the levels of the previous decade', ${ }^{26}$ a Supreme Court of Canada case decision created increased pressure on the capacity of Canada's refugee determination system. ${ }^{27}$

Data for this study was collected from elite interviews, primary historical documents including pertinent legal texts for Canada and Turkey, reports from various national and international organizations as well as parliamentary reports including minutes from committees working on international protection and migration and circulars in both countries. These texts were coded using a study-specific codebook designed for latent content analysis. ${ }^{28}$ The coding values used corresponded to the scoring structure of the ADVIAN classification scheme for impact analysis. ${ }^{29}$ This classification allows for the examination of impact, intensity of impact and relationships between and amongst factors and actors involved in a system. In this study, that system is the asylum system. Additionally, because ADVIAN classification produces calculated measures of impact, diverse cases can more usefully be compared with one another. Furthermore, systems delineated with the same factors can be compared across time. ${ }^{30}$

The ADVIAN classification is presented in a table format where actors and factors are displayed and their relationships in terms of impact are shown 
numerically based on a $0-3$ scale $(0=$ no impact; $1=$ low impact; $2=$ medium impact; 3 = high impact). This score is a qualitative score based on the latent content analysis. The tables below show the six factors' active and passive scores including overall or total active and passive impact. The factor scoring the highest along the active axis is considered the factor asserting the greatest influence. The factor scoring highest along the passive axis is considered the factor receiving the greatest influence. The factor with the highest combined active and passive score becomes the critical factor in the system; this factor is the one that when changed can affect the greatest cumulative change in the system. ${ }^{31}$

In order to create a generalizable set of factors, with potential utility across very different cases and time periods, each factor represents a broader definition and then a specific set of variables in each specific country or time. Parameters for each factor are outlined in Table 1.

\section{Canada}

Scholars suggest that Canada's immigration policy 'has evolved in relation to three main goals: nation-building and expansion of the economy and population; the needs of the contemporary labor market; and the long-term integration of immigrants. ${ }^{32}$ Such goals for immigration policy are distinct

Table 1. Factors in the asylum system.

\begin{tabular}{|c|c|}
\hline & FACTORS IN THE ASYLUM SYSTEM \\
\hline Asylum Law & $\begin{array}{l}\text { Includes national laws governing definitions, processes, rights of and } \\
\text { responsibilities towards asylum seekers as well as whether or not a } \\
\text { country is signatory to the } 1951 \text { Convention and } 1967 \text { Protocol and } \\
\text { how those international standards are translated into national law }\end{array}$ \\
\hline Refugee determination system & $\begin{array}{l}\text { Includes whatever system, organizations, persons, guidelines and } \\
\text { protocols are employed to make determinations on the legal and } \\
\text { administrative status of asylum seekers }\end{array}$ \\
\hline $\begin{array}{l}\text { Domestic policy preferences of } \\
\text { decision-makers }\end{array}$ & $\begin{array}{l}\text { Includes immigration and asylum policies and policy responses as well } \\
\text { as policies relating to or influencing asylum policy; in addition, } \\
\text { domestic policy preferences may include issues or interests that } \\
\text { arise that affect asylum policy or its implementation }\end{array}$ \\
\hline International context & $\begin{array}{l}\text { Includes events and relationships among nation-states and } \\
\text { international organizations with respect to asylum or issues that } \\
\text { affect asylum }\end{array}$ \\
\hline Historical experience & $\begin{array}{l}\text { Includes a country's past profile for taking refugees (international } \\
\text { expectations) moderated by whether or not past refugees have } \\
\text { been assisted or integrated successfully - whether or not a country } \\
\text { will see more refugees as manageable or an unmanageable burden; } \\
\text { this also includes the social and political conception of 'refugee' and } \\
\text { understanding of 'how to treat' a refugee (for example in need of } \\
\text { hospitality and safety or as a potential threat to local society) }\end{array}$ \\
\hline Local capacity & $\begin{array}{l}\text { Includes both willingness of local community to absorb refugee flows } \\
\text { and a country's economic capacity overall (\# of refugee applicants/ } \\
\text { GDP per capita - housing, support programs, services provided, } \\
\text { etc.) }\end{array}$ \\
\hline
\end{tabular}


from the rationale for international protection as outlined by the Geneva Convention. Therefore, Canada's commitment to resettle refugees has required a specific set of institutions and practices for which some are under the Ministry of Immigration and others are designed to be independent.

Canada created an independent quasi-judicial tribunal in 1989 called the Immigration and Refugee Board of Canada (IRB) charged with assessing asylum claims from the inland system, or spontaneous arrivals. While the UNHCR has maintained an office in Canada, it is only peripherally involved in the inland system as an official observer and has cooperated in particular matters of resettlement. The last component of the Canadian asylum system is border control. Canadian border officers have been empowered under and responsible for enacting a number of different asylum laws and regulations. The Immigration Act of 1976 governed the movement of people across Canadian borders for the period under study.

While each institution played a part in the asylum system, the largest part of the Canadian system resided within the process of refugee status determination through the IRB. When a person arrived with an asylum claim at the Canadian border and was found admissible, she/he was directed to go to the nearest IRB office in person. Offices were located in major Canadian cities: Montreal, Toronto, and Vancouver. The asylum seeker was given three days to report to an office to present his/her claim to the Refugee Protection Division (RPD) previously called the Committee for Refugee Determination Division (CRDD). It was with the creation of the IRB that Canada was able to implement the 1985 Supreme Court decision, also known as the Singh decision. ${ }^{33}$ This decision ruled that the Canadian Charter of Rights and Freedoms applied not only to Canadians but to anyone on Canadian soil. The Singh decision stipulated that under the Canadian Constitution, all asylum seekers at some point within their claims process had the right to an oral hearing. The adjudication process within the IRB followed the format of an administrative tribunal which differed from other adversarial processes in that the IRB Member(s) adjudicating the case shouldered the burden of understanding and assisting the claimant by providing any necessary information. ${ }^{34}$ If the claim was refused at the IRB, the claimant had the right to request a judicial review of the decision which was carried out by the Federal Court. ${ }^{35}$ If a claim was rejected and upheld through a court decision, the claimant was to be removed from Canada provided that return to the claimant's country of origin did not constitute breaking the principle of nonrefoulement.

Table 2 shows levels of impact each factor exerts within the system. The two factors exerting the most influence over the system (highest total active impact) are asylum law and domestic policy preferences of decision-makers. The factor receiving the most influence (highest total passive impact) is the refugee determination system. The critical factor with the highest combined 
Table 2. Canadian asylum system: impact analysis results for 1988-92.

\begin{tabular}{|c|c|c|c|c|c|c|c|c|c|}
\hline \multirow{2}{*}{\multicolumn{2}{|c|}{ CANADA }} & \multicolumn{6}{|c|}{ PASSIVE } & \multirow[b]{2}{*}{$\begin{array}{l}\text { ACTIVE } \\
\text { SUMS }\end{array}$} & \\
\hline & & $\begin{array}{c}\text { Asylum } \\
\text { law }\end{array}$ & \multirow{2}{*}{$\begin{array}{c}\text { Refugee } \\
\text { determination system } \\
3\end{array}$} & \multirow{2}{*}{$\begin{array}{c}\begin{array}{c}\text { Historical } \\
\text { experience }\end{array} \\
0\end{array}$} & \multirow{2}{*}{$\begin{array}{c}\text { International } \\
\text { context }\end{array}$} & \multirow{2}{*}{$\begin{array}{c}\begin{array}{c}\text { Local } \\
\text { capacity }\end{array} \\
2\end{array}$} & \multirow{2}{*}{$\begin{array}{c}\text { Domestic policy } \\
\text { preferences of decision- } \\
\text { makers }\end{array}$} & & \\
\hline ACTIVE & Asylum law & $x$ & & & & & & 7 & 30 \\
\hline & Refugee determination system & 2 & $x$ & 0 & 1 & 1 & 1 & 5 & \\
\hline & Historical experience & 0 & 3 & $x$ & 0 & 1 & 2 & 6 & \\
\hline & International context & 1 & 2 & 0 & $x$ & 0 & 1 & 4 & \\
\hline & Local capacity & 0 & 0 & 0 & 0 & $x$ & 1 & 1 & \\
\hline & $\begin{array}{l}\text { Domestic policy preferences of } \\
\text { decision-makers }\end{array}$ & 2 & 3 & 0 & 1 & 1 & $x$ & 7 & \\
\hline & PASSIVE TOTALS & $\begin{array}{r}5 \\
30\end{array}$ & 11 & 0 & 2 & 5 & 7 & & \\
\hline
\end{tabular}


active and passive total is the refugee determination system $(11,5)$ followed closely by domestic policy preferences of decision-makers $(7,7)$.

The high active scoring for asylum law can be attributed to the appeals process built into the Canadian asylum system. That appeals process, through which the Singh decision was made, produced a significant change in Canada's determination system. The high active score for domestic policy preferences of decision-makers appears due to a combination of government influences at various institutional levels. While the IRB was designed as an independent tribunal, the support staff were responsible to the Minister of Immigration. ${ }^{36}$ Additionally, the budget for the IRB was provided by the Ministry. Within the framework of Canadian immigration (1988-92), the Minister had significant and 'uncontrolled discretionary power ... potentially the last word on every individual case' regarding decisions of admission and deportation. ${ }^{37}$ Through such decision-maker influence, general immigration policies, such as concerns over a migrant's ability to integrate, could take precedence over the measures used to determine an asylum seeker's qualification as a Convention refugee. Because Canada is a geographically remote country, it has not received mass influxes of asylum seekers as have countries that border conflict zones. Between 1990 and 1992, Canada received asylum claims numbering 36,208, 30,552, and 37,743 respectively. ${ }^{38}$ Comparably, Canada resettled 39,651 refugees in 1990-91 and 35,463 refugees in 199192. ${ }^{39}$ Due to the amount of time required to adjudicate an asylum claim, annual claims did not correspond directly to resettlement statistics. However, the numbers show that Canada was receiving a relatively consistent number of claims and resettling a very similar number of refugees. This suggests that asylum seeker producing conflicts in the international context had a low impact on the Canadian system. Local capacity also had a low impact on the system as Canada is a very large country that did not experience resource challenges in resettling refugees. ${ }^{40}$

The highest passive factor and overall critical factor scores for refugee determination system can also be attributed to the large multi-year problem that was the Backlog. The backlog was 'a legacy of the previous system [before the IRB] ... in the form of a backlog of at least 85,000 claims involving over 100,000 people, all of whom had made refugee claims before January 1989'. ${ }^{41}$ In addition, the estimates for work hours needed at the IRB to clear the backlog and the reality were quite different. The 1990 IRB Annual Report pointed out that 'the IRB faced an annual caseload double than originally anticipated when the Board was first established [just two years previous]'. According to Immigration and Employment Canada's Annual Report 1990-91, there were 36,208 asylum claims made to Canada's inland system in 1990, whereas 1989 claims numbered 20,268. All of these claims were being addressed through the IRB. These numbers did not include the backlog which was simultaneously being addressed through a special 
Backlog Subdivision. ${ }^{42}$ The near doubling of claims in just one year represented significant pressure on the Canadian asylum system. Timely processing plans also created pressure on the refugee status determination system as seen in one of the main objectives in the annual report of Employment at Immigration Canada (EIC). It states that EIC aims 'to respond in a timely manner to applications for immigration or refugee status. ${ }^{43}$ In addition, 'the Minister stated that the clearance [of the backlog] would be completed within two years' ${ }^{44}$ thereby constituting additional decision-maker pressure on the adjudication process. The 1990 IRB Annual report states that ' $t$ t]he most important issue currently affecting the (CRDD) Division is its ability to determine claims for refugee status in an expeditious and fair manner given the large number of claimants that continue to enter the country. ${ }^{45}$ Therefore, the backlog represented pressure on the determination system through three factors: domestic policy preferences of decision-makers (to complete the claims quickly and affordably), historical experience (previous years had not been processed effectively enough), and asylum law (the Supreme Court of Canada decision stipulated part of the adjudication process).

The IRB impacts the score for the refugee determination system. The IRB, as a quasi-judicial independent tribunal, is independent of the government in terms of adjudicating asylum claims. ${ }^{46}$ However, policy preferences of decision-makers who can define the role and composition of the IRB influence the functioning of the IRB with respect to implementing asylum policy. Members are appointed by the Minister of Immigration. In the mid1990s, Member appointments were scrutinized to determine whether they had been based on merit or not. ${ }^{47}$ IRB Members being reappointed were questioned on their application and appointment process. ${ }^{48}$ Scrutiny persisted in subsequent years. In a public rebuttal to an opinion piece in the media, the IRB Chairperson, Brian Goodman responded to comments that Members' appointments were 'selected as much for their political connections as for their credentials ${ }^{49}$ in a parliamentary committee meeting:

The Government appoints IRB members from a list of candidates qualified by a Selection Advisory Board. Candidates undergo a transparent merit-based selection process which includes screening for suitability, a written test, an interview and reference checks. The IRB Chairperson recommends only those candidates who successfully complete this process. ${ }^{50}$

In addition to appointed independent Members (Chairperson, Executive Board Members and the regular Members (case officers and adjudicators)) the IRB administrative staff, including the Executive Director, have always been employees of the Government of Canada. Because the governmental employees were directly influenced by government changes and funding, the critical view is that IRB Members were then indirectly influenced by the 
government through the staffing thereby preventing the tribunal from being truly independent. ${ }^{51}$

According to the IRB, the pacing and level of its caseload was dictated by the Ministry as regulated by the existing legislation. In more explicit terms 'the CRDD is dependent upon Immigration Canada Case Presenting Officers and adjudicators who are responsible for scheduling claims, bringing cases forward to the panel and determining whether or not the Minister's representative will concede or contest each case. ${ }^{52}$ Therefore, domestic policy preferences of decision-makers, as represented by Ministry involvement in the presenting of caseloads, inquiry into Member appointments, and direct federal funding of the organization and its employees can be scored as having a medium impact on the refugee status determination system. Because the adjudication of claims was a highly structured, evidence-based decision-making process, it can be argued that there is still a level at which adjudication can be independent from the influences of domestic policy preferences of decision-makers.

\section{Turkey}

Turkey's general immigration policy has been primarily focused on nationbuilding since the beginning of the Republic in $1923 .{ }^{53}$ Additionally, 'Turkey aimed to facilitate the movement of foreigners into its territory in the period between 1990 and 2010, ${ }^{54}$ Until 1994, asylum policy response in Turkey was governed by components of a number of different national laws: Law 2510 (Law on Settlement), Law 5682 (Passport Law), Law 5683 (Law on the Stay and Travel of Foreigners). Turkey's migration policies more generally were subject to 'administrative discretion due to the dispersed nature of the legislation prior to the April 2013 Law on Foreigners and International Protec (LFIP), ${ }^{55}$ According to a Turkish legal scholar specializing in Turkish migration law, 'refugee' was a neglected concept in the laws governing the movement and rights of foreigners in Turkey until 2013 when Turkey introduced the LFIP. ${ }^{56}$ In addition, while Turkey became, and still is, a signatory to the 1951 Convention and the 1967 Protocol, Turkey has maintained the geographical restriction which stipulates that Turkey will only resettle refugees coming from conflict in Europe. As a consequence, Turkey developed an active working relationship with the $\mathrm{UNHCR}^{57}$ which has been responsible for refugee status determination for asylum applications made by non-Europeans. Moreover, asylum seekers who received a favorable refugee status determination had to relocate, with the assistance of the UNHCR, to a third country for resettlement. As a Convention signatory that maintains the geographical restriction, Turkey maintains a legal commitment to nonrefoulement and has a history of acting as a country of first asylum to nonEuropean asylum seekers. 
Between 1988 and 1992, when over 500,000 Iraqis fled the war in Iraq and entered Turkey, no specific asylum policy had been developed yet. Additionally, up until the arrival of the Iraqis, 'Turkish parliament [had] never enacted a law comprehensively regulating asylum and related issues. ${ }^{58}$ The Turkish government responded to the late 1980s influx by establishing an Administration Center under the State Ministry with a State Minister provisionally assigned to watch over the implementation of the measures. The Administration Center was created to enable efficient coordination among the ministries and other institutions attending to the mass influx as well as ensure flow of information across all levels of administration about problems arising and solutions devised. ${ }^{59}$ Additionally, there were Local Communication Units as well as Coordination and Support Centers established in six municipalities in eastern Turkey. These local institutions mainly focused on providing humanitarian assistance while the UNHCR, working within Turkey, was involved in asylum procedures, refugee status determination and resettlement. ${ }^{60}$ The Turkish case is characterized by tension amongst the factors constituting the asylum system. For the 1988-92 period, with asylum law not yet been designed to deal with the mass influx, particularly from non-European countries, there was no nationally administered refugee determination system for this group. The actors and organizations that comprised the asylum system responded provisionally and had to manage complex communication streams sometimes differing in interpretation of 'the rules' that regulated domestic implementation of international protection obligations. ${ }^{61}$ Additionally, as of the 1990s, conflicts in surrounding geographical areas began producing larger refugee flows than previously experienced by Turkey. This resulted in high pressure on the Turkish asylum system in the period under study.

In Table 3, the highest total active impact, historical experience (10), is attributable to Turkey's experience of mass influx beginning in 1980 when 'Iranians [entered Turkey] fleeing the new regime in Iran ... [for which] Turkey adopted a policy which enabled Iranians to enter the country without a visa... and stay temporarily'. ${ }^{62}$ The high total active impact of the international context (9) is attributable to asylum flows into Turkey from Iran and Iraq in the 1980s and 90s. The highest total passive impact, the refugee determination system (13), is constituted by the tandem process of registration and refugee status determination that asylum seekers had to follow between the Turkish Police and the UNHCR. Also with a high total passive impact, domestic policy preferences of decision-makers (10) is attributable to Turkey's continued migration policy focus on nation-building and citizenship, not removing the geographical restriction and, at the time, 'Officials [being] concerned that militants of the Kurdistan Workers' Party (PKK) were among [the] asylum seekers [entering from Iraq]'. ${ }^{63}$ Asylum law $(6,7)$ is constituted by the three main laws governing the movements 
Table 3. Turkish asylum system: impact analysis results for 1988-92.

\begin{tabular}{|c|c|c|c|c|c|c|c|c|c|}
\hline \multirow{2}{*}{\multicolumn{2}{|c|}{ TURKEY }} & \multicolumn{6}{|c|}{ PASSIVE } & \multirow[b]{2}{*}{$\begin{array}{c}\text { ACTIVE } \\
\text { SUMS }\end{array}$} & \\
\hline & & $\begin{array}{l}\text { Asylum } \\
\text { law }\end{array}$ & $\begin{array}{c}\text { Refugee } \\
\text { determination system }\end{array}$ & $\begin{array}{l}\text { Historical } \\
\text { experience }\end{array}$ & $\begin{array}{l}\text { International } \\
\text { context }\end{array}$ & $\begin{array}{l}\text { Local } \\
\text { capacity }\end{array}$ & $\begin{array}{l}\text { Domestic policy preferences } \\
\text { of decision-makers }\end{array}$ & & \\
\hline \multirow[t]{7}{*}{ ACTIVE } & Asylum law & $x$ & 3 & 0 & 1 & 1 & 1 & 6 & 44 \\
\hline & $\begin{array}{l}\text { Refugee determination } \\
\text { system }\end{array}$ & 1 & $\mathrm{x}$ & 0 & 1 & 2 & 2 & 6 & \\
\hline & Historical experience & 1 & 2 & $x$ & 2 & 2 & 3 & 10 & \\
\hline & International context & 2 & 3 & 0 & $x$ & 1 & 3 & 9 & \\
\hline & Local capacity & 1 & 2 & 0 & $\hat{1}$ & $x$ & 1 & 5 & \\
\hline & $\begin{array}{l}\text { Domestic policy preferences } \\
\text { of decision-makers }\end{array}$ & 2 & 3 & 0 & 2 & 1 & $x$ & 8 & \\
\hline & PASSIVE SUMS & $\begin{array}{r}7 \\
44\end{array}$ & 13 & 0 & 7 & 7 & 10 & & \\
\hline
\end{tabular}


of foreigners in Turkey as well as the 1951 Convention. Local capacity $(5,7)$ is constituted by the provisional institutions set up to administer and manage the emergency response and support services provided for asylum seekers. With the highest combined active and passive impact scores, the refugee determination system $(13,6)$ and domestic policy preferences of decision-makers $(10$, 8) represent critical factors in Turkey's asylum policy system.

Local capacity and asylum law, as factors, receive the lowest scores in the system, however they both have some impact. Turkey had local capacity, for example, in the form of unused structures such as the temporary apartment blocks in Lice repurposed as the Diyarbakir-Yenikent Shelter, originally built to house earthquake victims. The apartment blocks were used to house 10,000 asylum seekers from Iraq in 1991, including children. ${ }^{64}$ Asylum law also had an impact on the system, particularly in the form of maintaining the geographical restriction, and applying the principle of nonrefoulement while prioritizing temporariness of the stay of those who sought international protection. Since Iraqi asylum seekers, as non-Europeans, would not be considered for resettlement in Turkey, the role of the UNHCR became central to Turkey's refugee determination system.

The historical experience of the mass influx from Iran in the earlier part of the 1980s, was based on the rough calculation that Turkey hosted between 600,000 and one million Iranians as they fled to other countries. ${ }^{65}$ Despite this experience, Turkey maintained its asylum governance through a collection of laws addressing the movement of foreigners and the domestic policy preferences of decision-makers until the LFIP came into force in 2013. The asylum system persisted in responding to the asylum flows on a provisional basis without developing a targeted policy on responding to mass influx or international protection needs.

The critical factors, those with the highest combined active and passive impact on change (or lack thereof) in the asylum system, are the refugee determination system $(13,6)$ and domestic policy preferences of decision-makers $(10$, 8). As critical factors, they have the greatest potential to shift other factors' impacts in the system. The refugee determination system becomes a critical factor largely due to its high total passive score (13) impacted the most by asylum law, the international context and domestic policy preferences of decision-makers. First, asylum law impacts the refugee determination system through the Law on Settlement which stipulates that only those people entering Turkey as forced migrants and intending to stay temporarily will be considered refugees. ${ }^{66}$ Second, the sheer number of asylum seekers entering Turkey, representing impact from the international context, challenged the capacity and efficiency of the refugee determination system. Domestic policy preferences of decision-makers, with a focus on security and concerns over the entry of PKK militants, intensified the need to register each asylum seeker who crossed into Turkey leading to increased pressure 
on services. In addition to receiving sizeable impact, the refugee determination system also impacted local capacity in that the requirement to register and manage the influx of asylum seekers resulted in the creation of the provisional Administration Centre, Ministerial role, and further support institutions. Moreover, the refugee determination system, as a two-step application process for asylum seekers hoping to be resettled rather than returning to Iraq, was partially constituted by the UNHCR which 'had full engagement in terms of exercising its mandate'. ${ }^{67}$ As such, the UNHCR component of the refugee determination system had an impact on domestic policy preferences of decision-makers in making international refugee status determinations and organizing resettlement options for those asylum seekers whose claims were recognized.

\section{Comparative analysis of ADVIAN scores}

Canada and Turkey responded to high pressure situations that stressed the capacity of their existing asylum systems from the 1980s onwards. Turkey received mass influx of Iraqi asylum seekers, who started entering Turkey in 1988 and continued along a punctuated time line through 1991 and thereafter. Canada tried to operate a brand-new functioning IRB developed in response to the Singh Decision of 1985 as well as the large number of backlogged claims that the decision created.

First, Canada and Turkey both opted for institutional reform in responding to asylum claims; however, the reforms were different. Canada opted to create a new institution, the IRB, to address the high number of asylum claims in the late 80 s and early 90 s. A few years later, in the mid-90s, Turkey introduced the 1994 Regulation to clarify the status determination process for asylum seekers. The Regulation amended the existing legal framework while preserving the existing institutions responsible for the asylum system, and it clarified the division of responsibilities, protocols and procedures regarding the authority of the Turkish state and the roles of the UNHCR and NGOs concerning asylum seekers and refugees in Turkey. The Regulation required that asylum seekers register with the National Police within 5 days of entering Turkey after which they were permitted to file a claim with the UNHCR. Initial registration with the National Police was critical for being able to obtain a valid exit visa should an asylum seeker be qualified for resettlement in a third country. ${ }^{68}$ Previous to the 1994 Regulation, there had been cases of asylum seekers who entered Turkey without registering with the National Police, effectively illegally, then obtained refugee status determinations through the UNHCR. These cases were discovered when the refuges came to the Turkish border to exit for a third country. ${ }^{69}$ The 5-day stipulation has been subject to criticism by scholars, NGOs and the international community. ${ }^{70}$ The Regulation addressed the dilemma of Turkey's sovereign right to control entry and exit 
across its borders as well as ensure appropriate processing of international protection claims by those arriving from Iraq. After a few years in practice, the 5-day stipulation was extended to 10 days in the 1999 amendment to the Regulation. However, the geographical restriction was maintained. Just over a decade later, in 2013, the LFIP came into force, still with the geographical restriction in place.

Second, the timing of the response with respect to amending asylum law was different in both cases. In the Turkish case, as noted above, while there was no immediate regulation in response to the mass influx of Iraqi asylum seekers between 1988 and 1992, in the same period the Bulgarian Turks fleeing persecution in Bulgaria into Turkey merited an immediate amendment, Law No. 3583 (16 June 1989), to the Law on Settlement. This amendment reinforced the spirit of the Law on Settlement by emphasizing Turkish descent as qualification for entry and settlement. Bulgarian Turks were permitted to immigrate based on their Turkish descent and were also assisted with their citizenship acquisition and settlement in the country. ${ }^{71}$ In the Canadian context, the Singh case had forced the Supreme Court to reconsider who was afforded a hearing according to the Canadian Constitution. The question rested on who was availed of the right, citizens or all people on Canadian soil? The Court decided the Constitution referred to all people whether they held Canadian citizenship or not. While both countries' laws were amended, or reinterpreted from experience with unforeseen increase in arrivals, Turkey's reinterpretation reinforced the focus on Turkish descent for settlement while Canada's interpretation expanded the application to all people on Canadian soil. The different outcomes of the amendments to existing laws were consistent with the existing domestic policy preferences of decision-makers in identifying the core principles that governed asylum in both countries.

Third, the most striking difference between the ADVIAN tables of both cases is the difference in the sums of the scores for the active and passive factors as 30 for Canada and 44 for Turkey. This variation is a consequence of higher impact scores assigned to each of the factors in the Turkish case compared to the Canadian case. Such higher scores mean that in the Turkish case more influence was being exerted amongst factors creating a more dynamic system. In the Turkish case, there was a collection of laws and regulations governing asylum and a mix of actors, including the UNHCR, cooperating in the implementation of international obligations, leading to increased dynamism in the system. Moreover, lack of a single asylum policy governance agency, institution or structure in the Turkish case meant less institutional learning and memory. Dynamism in the Canadian case is limited to interaction within a set of institutions which leave comparatively little room for discretion and interpretation aside from Supreme Court decisions. 
The above analysis points to a stark contrast in how Canada and Turkey responded to immediate high pressure on their asylum systems. However, while the systems have different highest active factors (Canada: asylum law and domestic policy preferences; Turkey: historical experience and international context), their highest passive factors are the same (refugee determination system and domestic policy preferences of decision-makers). Similarly, their two critical factors, those with the highest combined active and passive scores, are the same (refugee determination system and domestic policy preferences of decision-makers). Despite their differences, the impact in the Canada and Turkey cases is received by the same factors and is therefore able to be similarly modified by any changes to those factors. Therefore, this study concludes that changes to either case's refugee status determination system or domestic policy preferences of decision-makers would have the greatest impact on the entire asylum policy system.

\section{Conclusion}

This study examines the reasons behind a quandary afflicting the state of affairs in international protection: While numbers of those escaping crisis, conflicts, wars, persecution, and natural disasters increase, industrialized countries willing to accept and resettle asylum seekers and refugees in large numbers decrease. Moreover, high- and middle-income states receiving victims of forced migration, ever more, tend to adopt more restrictive asylum policies; why? This study addresses a major theoretical gap in responding to this question by analyzing evidence at the onset of the trend towards restriction through two diverse cases, Canada and Turkey, for an intense asylum flow period (1988-92) utilizing a complex impact analysis based on the ADVIAN classification scheme.

The findings, first, indicate that the institutional core of the design of a country's refugee determination system is critical in shaping a country's policy response to emerging asylum challenges. For example, in response to the 1988-92 asylum flows, Canada maintained the application of the Charter to all on Canadian soil while Turkey safeguarded its application of the geographical restriction to the 1951 Convention as well as the principle of Turkish descent for settlement. Second, domestic policy preferences of decision makers influence the extent to which and in what ways historical experience and international context impact asylum policy change by mediating the process of incorporation of those factors into the policy outputs at a given time in response to a certain challenge. In a similar international context, therefore, policy makers devised distinct domestic policy structures: While Turkey aimed to proceed through the challenge with a provisional administrative structure, Canada introduced a new and permanent institution, the IRB. 
Third, the conclusions point out that researchers need to closely examine complex interactions among domestic institutions and variation in the levels of impact of a range of causal factors on asylum policy change. The findings validate that historical experience ${ }^{72}$ and backlash to mass influxes of the $1980 \mathrm{~s}^{73}$ may facilitate explaining the emergence of restrictive asylum policies in certain periods, however, only to the extent that domestic policy preferences of decision makers account for them. Hence, comparative studies, such as this one, focusing on time frames of intense international pressures on refugee receiving states are more likely to reveal the foundations of restrictive asylum policies across cases. By doing so, as shown in this study, researchers will be able to identify a range of causal factors, intervening processes and their comparative impact on asylum policy outcomes. Accordingly, studies on asylum policy change will advance beyond explaining current restrictive asylum policy responses through the rise of the 'radical right', intensifying hostility toward refugees and/or major economic strain experienced in refugee receiving states, ${ }^{74}$ and account for the multifaceted interactions that form the asylum policy domain. Moreover, a dense study of the findings also highlights the significance of examining the origins of restrictive asylum policies for explaining their trajectories over time.

The conclusions of this study also imply that examining the origins of restrictive asylum policies is significant for understanding their trajectories over time for individual states and also for collaborative efforts. The surge in the number of refugees in the post-2011 period accelerated global debates and efforts around developing new collaboration venues for respecting refugee rights such as the New York Declaration for Refugees and Migrants and the Global Compact for Refugees process. Many stakeholders made an impressive effort to contribute to the drafting of the text and highlighted its capacity to redefine international dynamics of international protection toward more respect for refugee rights and reasonable responsibility sharing among all states. The findings of this study reveal that even the advent of an international cooperation mechanism for promoting refugee rights or durable solutions does not diminish the likelihood of persistent restrictive asylum policies of states, or even collaboration for more restrictive measures on asylum among industrialized states. This is because, this study claims, domestic institutions and interactions among them primarily shape asylum policies, and there is a resolve by national preferences for restrictive asylum policies to prevail. Consequently, based on the findings of this study, the need for further research on explaining the origins of the restrictive asylum policies is even more crucial in the current period in order to improve dialogue, collaboration and implementation efforts among IOs, NGOs, the public, and receiving states to construct and sustain a human-rights focused refugee regime. 


\section{Notes}

1. Castles and Loughna, "Trends in Asylum Migration;" Hatton, "Rise and Fall of Asylum."

2. See http://www.unhcr.org/resettlement.html.

3. de Haas et al., "Growing Restrictiveness Changing Selection."

4. Jacobsen, "Factors Influencing Policy Responses."

5. Castles and Loughna, "Trends in Asylum Migration."

6. Betts, Survival Migration.

7. Norris, Rise of the Radical Right.

8. Czaika, "Political Economy of Refugee Migration."

9. Hatton, Seeking Asylum.

10. Benhabib, "Citizens, Residents and Aliens," 734.

11. Gammelhoft-Hansen, "Extraterritorialisation of Asylum."

12. Safe-third country agreements occur when a refugee receiving country officially deems another country to be 'safe' and will not accept an asylum seeker who has entered through that country based on the concept that asylum must be claimed in the first possible safe country; see de Haas et al., "Growing Restrictiveness Changing Selection." The Pacific Solution was an Australian policy between 2001 and 2007 through which spontaneous arrivals were relocated to detention centers on island nations off Australia's coast to make their asylum claims from there; see Frelick et al., "The Impact of Externalization." FRONTEX is the European agency that coordinates and manages the external borders of the EU. As of 2015, FRONTEX includes border and coastguard services; see Frelick et al., "The Impact of Externalization." The EASO is the European Asylum Support Office is an EU agency that provides support, expertise and coordination for member states regarding asylum issues; see https:// www.easo.europa.eu/. The Stockholm Program (2010-2014 was "a framework for EU action on the issues of citizenship, justice, security, asylum, immigration and visa policy for the period 2010-2014." https://ec.europa.eu/anti-trafficking/ eu-policy/stockholm-programme-open-and-secure-europe-serving-andprotecting-citizens-0_en. Also see Triandafyllidou, "Externalizing Migration and Asylum."

13. Global Trends 2010.

14. The EU-Turkey Statement was announced on 18 March 2016. The main objective of the deal is to curb irregular migration through cooperation between Turkey and the EU through implementing a set of actions. Irregular migrants from Turkey to Greek islands are to be returned from 20 March 2016. For every Syrian returned to Turkey, one will be resettled from Turkey to the EU. Turkey will implement measures to prevent illegal crossings to the EU. A Voluntary Humanitarian Admission Scheme will be implemented subject to the progress on curbing illegal crossings from Turkey to the EU. The visa liberalization roadmap for removing visa requirements for Turkish citizens to the EU will be accelerated. The EU will contribute 3 billion euros to Turkey's efforts in addressing the needs of refugees through the Facility for Refugees in Turkey. Also see http://www.consilium.europa.eu/en/press/press-releases/2016/03/18/ eu-turkey-statement/. The deal has been received with a lot of ciritcism by NGOs and academics for its policy implications for international protection in general, see Haferlach and Kurban, "Lessons Learned."

15. For more information on case study design and diverse case studies, see Seawright and Gerring, "Case Selection Techniques." 
16. Seawright and Gerring, "Case Selection Techniques."

17. Hawkins, Canada and Immigration.

18. İçduygu and Kirişci, Land of Diverse Migrations; Kirişci, Justice and Home Affairs.

19. Burgin, "European Commission's Agency."

20. Sirkeci and Cohen, "Cultures of Migration and Conflict."

21. Migrationpolicy.org, "Annual Number of New Asylum."

22. Migrationpolicy.org, "Annual Number of New Asylum."

23. Baklacıoğlu, "Historical Memory of Asylum;" Frelick, "Barriers to Protection;" Aksel and Danış, "Diverse Facets of Europeanization;" Kirişci and Karaca, "Hoşgörü ve Çelişkiler."

24. Freeman, "Migration Policy and Politics," 1152; Knowles, Strangers at Our Gates, 224.

25. Knowles, Strangers at Our Gates, 228.

26. Ibid., 238.

27. The Singh Decision.

28. Latent content analysis refers to analysis of text or communication in which the contextual meaning of the language or message is coded in order to summarize larger texts into useful categories. This form of content analysis differs from manifest content analysis where latent content analysis is used to code the meaning in text, manifest content analysis is used to code or score the frequency of the use of textual references. Latent content analysis is used in this study to identify, code and score textual interpretations of influence among the 'six factors'. For a good literature review on content analysis and uses of latent content analysis, please see Hsieh and Shannon, "Three Approaches to Qualitative."

29. Linss and Fried, "The ADVIAN Classification."

30. ADVIAN classification of Impact Analysis is a method published by Andreas Fried and Volker Linss utilized in systems and organizational analysis. The tool allows for qualitative textual and expert information to be scored and tabulated to assess the impact or influence among a set of factors in a system. This scoring or tabulation then facilitates analysis of the most influential factors in a system, the factors receiving the most impact from others and relationships of influence among the factors. Qualitative textual data is scored on a scale of impact between 0 and 3 where 0 means no impact and 3 means high impact. For the purpose of this study, textual data (documents and interviews) were examined for language that represented the six factors constituted in this study. Relevant phrasing and comments were scored (0-3) according to a codebook developed specifically for this study. Factor scores were then calculated from coded texts. For more information on ADVIAN classification see Linss and Fried, "The ADVIAN Classification" and Fried and Linss, "Towards an Advanced Impact." For information on the codebook for this study, please contact the authors.

31. Fried and Linss, "Towards an Advanced Impact."

32. Reitz, "Canada: New Initiatives."

33. The Singh Decision.

34. Interviewee $\# 5$.

35. http://www.irb-cisr.gc.ca/Eng/BoaCom/references/procedures/Pages/index. aspx.

36. Interviewee $\# 5$. 
37. Hawkins, Canada and Immigration, 102.

38. Immigration and Refugee Board of Canada, Annual Report 1990; Immigration and Refugee Board of Canada, Annual Report 1991; Immigration and Refugee Board of Canada, Annual Report 1992.

39. Employment and Immigration Canada, Annual Report 1990-91; Employment and Immigration Canada, Annual Report 1991-92.

40. Interviewee \#3.

41. Blackburn, Refugee Claimant Backlog Clearance.

42. Immigration and Refugee Board of Canada, Annual Report 1990.

43. Employment and Immigration Canada, Annual Report 1990-91; Employment and Immigration Canada, Annual Report 1991-92.

44. Blackburn, Refugee Claimant Backlog Clearance.

45. Immigration and Refugee Board of Canada, Annual Report 1990, 19.

46. Interviewee $\# 5$.

47. Interviewee $\# 5$.

48. Standing Committee on Citizenship and Immigration, Meeting No. 10.

49. Kohler, "Crackdown on Queue Jumpers."

50. Ibid.

51. Interviewee \#5.

52. Immigration and Refugee Board of Canada, Annual Report 1990, 20.

53. Interviewee \#1.

54. Genç, "Turkey's Bordering Processes."

55. Özçürümez and Şenses, "Limits to Regulating Irregular Migration," 454.

56. Interviewee \#1.

57. Interviewee \#3.

58. Kaya, “The Iraqi Refugee Crisis,” 3.

59. Kaynak, The Iraqi Asylum Seekers.

60. Kaynak, The Iraqi Asylum Seekers; Interviewee \#4.

61. Interviewee \#3.

62. Kirişci, "Disaggregating Turkish Citizenship," 11.

63. Kirişci, Justice and Home Affairs, 174.

64. Kaynak, The Iraqi Asylum Seekers, 56.

65. Özcan and Özdamar, "Uneasy Neighbours."

66. Law No. 2510 [1934] art 3. Scholars note that the Law on Settlement defines Turkey's approach to asylum seekers for many decades including the 19881992 period. Accordingly, how the refugee status determination process proceeds and how refugees are settled are determined by Turkish origin of the claimants. See also İnan, "Türkiye'de Göç Politikaları;” Kirişci, "Disaggregating Turkish Citizenship:" Kadirbeyoğlu and Çınar, "Migration and Citizenship in Turkey."

67. Interviewee \#4.

68. Interviewee \#3.

69. Kirişci, "Lifting the Geographical Restriction," 299.

70. Suter, "Asylum and Migration Policy," 19; The 5-day rule requires that the "refugee claimants ... apply within five days to local Governorates if they entered the country legally, or, if they entered illegally, to present themselves to Governorates in the city where they entered the country, also within five days." Frelick, "Barriers to Protection," 12. Major criticisms were raised on the 5-day rule around (i) the proper application of the principle of non-refoulement, Amnesty International, Refoulement of non-European Refugees; (ii) 
human rights violations around asylum claims, Human Rights Watch, "Protecting Refugees;" (iii) challenges to fair hearing of the cases of refugee claimants in a short period of time, (iv) avoiding of 'orbit cases' whereby the refugee claimants would not be able to file applications in different cities (v) increased emphasis on securitization of international protection in Turkey. Frelick, "Barriers to Protection." The consequences of the 5-day stipulation for Iraqis have been more severe after 1994 because the Iraqis who did not become part of the 'one-time solution' and who sought to apply for asylum after five-day limit have been deported to Iraq. Frelick, "Barriers to Protection," 18.

71. Kadirbeyoğlu and Çınar, "Migration and Citizenship in Turkey," 196; Danış and Parla, "Nafile Soydaşlik."

72. Jacobsen, "Factors Influencing Policy Responses."

73. Castles and Loughna, "Trends in Asylum Migration."

74. Norris, Rise of the Radical Right; Czaika, "Political Economy of Refugee Migration," and Hatton, Seeking Asylum.

\section{Acknowledgement}

This article is based on original research conducted by Christina Hamer as part of her $\mathrm{PhD}$ Dissertation at Bilkent University, Department of Political and Public Administration.

Both authors would like to thank Professor Oliver Schmidtke and his team for support for the year Christina Hamer spent as a Visiting $\mathrm{PhD}$ researcher at the University of Victoria Centre for Global Studies. The authors would also like to thank Dr. Selin Akyuz, anonymous reviewers and the editor for their valuable comments and suggestions on earlier versions of the article.

\section{Disclosure statement}

No potential conflict of interest was reported by the authors.

\section{Notes on contributors}

Saime Özçürümez is Director of the FEASS Human Mobility Interactions and Processes (HMPI) Research Lab and Associate Professor in the Department of Political Science and Public Administration at Bilkent University.

Christina Hamer is a PhD Candidate in the department of Political Science and Public Administration at Bilkent University.

\section{ORCID}

Saime Özçürümez (D) http://orcid.org/0000-0003-3957-6915

Christina Hamer (D) http://orcid.org/0000-0002-9618-0610

\section{Bibliography}

Agnus, William, and James Hathaway. "Deterrents and Detention: An Ill-Conceived Afterthought." Refuge: Canada's Journal on Refugees 7, no. 1 (1987): 8-9. 
Aksel, Damla, and Didem Danış. "Diverse Facets of Europeanization at the Iraqi Turkish Border." In Turkey Beyond the Fortress Paradigm at the Southeastern Borders of the EU, edited by N. Özgur Baklacıoğlu and Yeşim Özer, 267-297. Lexington: Edwin Mellen Press, 2013.

Asylum Trends 2014: Levels and Trends in Industrialized Countries. United Nations High Commissioner for Refugees, 2014. http://www.unhcr.org/statistics/ unhcrstats/551128679/asylum-levels-trends-industrialized-countries-2014.html.

Baklacioğlu, Nurcan Ö. "Historical Memory of Asylum Policy in Turkey: Ottoman Legacies and Syrian Refugee 'Crisis' Challenges." Review of History and Political Science 5, no. 2 (2017): 11-22.

Benhabib, Seyla. "Citizens, Residents and Aliens in a Changing World: Political Membership in the Global Era." Social Research 66, no. 3 (1999): 709-744.

Betts, Alexander. Survival Migration Failed Governance and the Crisis of Displacement. Ithaca and London: Cornell University Press, 2013.

Blackburn, Jean-Pierre. The Refugee Claimant Backlog Clearance: The Second Report of the Standing Committee on Labour, Employment and Immigration. 34th Parliament of Canada, 1989.

Burgin, Alexander. “European Commission's Agency Meets Ankara’s Agenda: Why Turkey is Ready for a Readmission Agreement." Journal of European Public Policy 19, no. 6 (2012): 883-899.

Castles, Stephen, and Sean Loughna. "Trends in Asylum Migration to Industrialized Countries: 1990-2001." WIDER Discussion Papers//World Institute for Development Economics (UNU-WIDER), No. 2003/31. http://hdl.handle.net/ $10419 / 52954$.

Czaika, Mathias. “The Political Economy of Refugee Migration,” Discussion Paper Series//University of Freiburg, Department of Economic Policy, No. 7, 2009. http://hdl.handle.net/10419/47899.

Danış, Didem, and Ayşe Parla. "Nafile Soydaşlık: Irak ve Bulgaristan Türkleri örneğinde göçmen, dernek ve devlet.” Toplum ve Bilim 114 (2009): 131-158.

de Haas, Hein, Katharina Natter, and Simona Vezzoli. "Growing Restrictiveness or Changing Selection? The Nature and Evolution of Migration Policies." International Migration Review, Open access, (2016): 1-44. doi:10.1111/imre. 12288.

Employment and Immigration Canada. Annual Report, 1990-91. Hull: Public Affairs Employment and Immigration Canada, 1991.

Employment and Immigration Canada. Annual Report, 1991-92. Hull: Public Affairs Employment and Immigration Canada, 1992.

Freeman, Gary P. "Migration Policy and Politics in the Receiving States." International Migration Review 26, no. 4 (1992): 1144-1167.

Frelick, Bill. "Barriers to Protection: Turkey's Asylum Regulations.” International Journal of Refugee Law 9, no.1 (1997): 8-34.

Frelick, Bill, Ian M. Kysel, and Jennifer Podkul. "The Impact of Externalization of Migration Controls on the Rights of Asylum Seekers and Other Migrants." Journal on Migration and Human Security 4, no. 4 (2016): 190-220.

Fried, Andrea, and Volker Linss. "Towards an advanced impact analysis of intangible resources in organisations." Lehrstuhlpapiere // Professur für Innovationsforschung und Nachhaltiges Ressourcenmanagement, no. 2, (2005). https://www.econstor.eu/bitstream/10419/55390/1/684989948.pdf.

Gammelhoft-Hansen, Thomas. "The Extraterritorialisation of Asylum and the Advent of 'Protection Lite," DIIS Working Paper 2007/2, Danish Institute for 
International Studies, 2007. https://www.econstor.eu/bitstream/10419/84510/1/ DIIS2007-02.pdf.

Genç, Deniz. "An Analysis of Turkey's Bordering Processes: Why and Against Whom?” Turkish Studies 16, no. 4 (2015): 527-553.

Gerring, John. "Is There a (Viable) Crucial-Case Method?" Comparative Political Studies 40, no. 3 (2007): 231-253.

Global Trends 2010. United Nations High Commissioner for Refugees, 2011. http:// www.unhcr.org/gr10/index.html\#/home.

Global Trends 2011. United Nations High Commissioner for Refugees, 2012. http:// www.unhcr.org/4fd6f87f9.pdf.

Government of Canada. Immigration Act 1976. http://www.refworld.org/docid/ $3 \mathrm{ae} 6 \mathrm{~b} 5 \mathrm{c} 60 . \mathrm{html}$.

Haferlach, Lisa, and Dilek Kurban. "Lessons Learned from the EU-Turkey Refugee Agreement in Guiding EU Migration Partnerships with Origin and Transit Countries." Global Policy 8, Supplement 4 (2017): 85-93.

Hatton, Timothy. Seeking Asylum: Trends and Policies in the OECD. London: Centre for Economic Policy Research, 2011.

Hatton, Timothy. "The Rise and Fall of Asylum: What Happened and Why?" The Economic Journal 119 (2009): F183-F213.

Hawkins, Freda. Canada and Immigration: Public Policy and Public Concern. Montreal and Kingston: McGill-Queens University Press, 1988.

Hsieh, Hsiu-Fang, and Sarah E. Shannon. "Three Approaches to Qualitative Content Analysis." Qualitative Health Research 15, no. 9 (2005): 1277-1288.

Human Rights Watch. "Protecting Refugees." In Turkey: Human Rights and the European Union Accession Partnership. 2000. https://www.hrw.org/reports/2000/ turkey2/index.htm\#TopOfPage.

İçduygu, Ahmet, and E. Fuat Keyman. "Globalization, Security, and Migration: The Case of Turkey.” Global Governance 6 (2000): 383-398.

İçduygu, Ahmet, and Kemal Kirişci. Land of Diverse Migrations: Challenges of Emigration and Immigration in Turkey. Istanbul: İstanbul Bilgi Üniversitesi Yayinları, 2009.

Immigration and Refugee Board of Canada. Annual Report 1990. Ottawa: Immigration and Refugee Board of Canada, 1990.

Immigration and Refugee Board of Canada. Annual Report 1991. Ottawa: Immigration and Refugee Board of Canada, 1991.

Immigration and Refugee Board of Canada. Annual Report 1992. Ottawa: Immigration and Refugee Board of Canada, 1992.

İnan, Canan Emek. “Türkiye'de Göç Politikaları: İskan Kanunları Üzerinden Bir İnceleme.” Göç Araştırmaları Dergisi 2, no. 3 (2016): 10-33.

Jacobsen, Karen. "Factors Influencing the Policy Responses of Host Governments to Mass Refugee Influxes.” International Migration Review 30, no. 3 (1996): 655-678.

Kadirbeyoğlu, Z. and Dilek Çınar. "Migration and Citizenship in Turkey.” In Turkish Migration Policy, edited by I. Sirkeci and B. Pusch, 183-203. London: Transnational Press, 2016.

Kaya, Ibrahim. "The Iraqi Refugee Crisis and Turkey: A Legal Outlook," CARIM Analytic and Synthetic Notes; 2009/20; Legal Module, 2009. http://cadmus.eui. eu/handle/1814/11298.

Kaynak, Muhteşem, ed. The Iraqi Asylum Seekers and Turkiye (1988-1991). Ankara: Tanmak Publications, 1992. 
Kirişci, Kemal. "Disaggregating Turkish Citizenship and Immigration Practices." Middle Eastern Studies 36, no. 3 (2000): 1-22.

Kirişci, Kemal. Justice and Home Affairs Issues in Turkish-EU Relations: Assessing Turkish Asylum and Immigration Policy and Practice, 2015. http://tesev.org.tr/wp-content/ uploads/2015/11/Justice_And_Home_Affairs_Issues_In_Turkish_EU_Relations.pdf.

Kirişci, Kemal. "Is Turkey Lifting the 'Geographical Limitation'? - The November 1994 Regulation on Asylum in Turkey" International Journal of Refugee Law 8, no. 3 (1996): 293-318.

Kirişci, Kemal. "Turkish Asylum Policy and Human Rights." In Human Rights in Turkey, edited by Zehra F. Kabasakal Arat, 170-186. Philadelphia: University of Pennsylvania Press, 2007.

Kirişci, Kemal, and Sema Karaca. "Hoşgörü ve Çelişkiler: 1989, 1991 ve 2011'de Türkiye’ye Yönelen Kitlesel Mülteci Akımları.” In Türkiye’nin Göç Tarihi: 14. Yüzyıldan 21. Yüzyıla Türkiye'ye Göçler, edited by M. Murat Erdogan and Ayhan Kaya, 297-310. Istanbul: İstanbul Bilgi Üniversitesi Yayınları, 2015.

Knowles, Valerie. Strangers at Our Gates: Canadian Immigration and Immigration Policy 1540-2006. Toronto: Dundurn Press, 2007.

Kohler, Nicholas. 2009. "A Crackdown on Queue-Jumpers: Will the Tories Make Bogus Refugee Claims an Election Issue?” Macleans Magazine, July 28. http:// www.macleans.ca/news/canada/a-crackdown-on-queue-jumpers/.

Latif, Dilek. "Refugee Policy of the Turkish Republic." The Turkish Yearbook 33 (2002): 1-29.

Linss, Volker and Andrea Fried. "The ADVIAN" Classification - A New Classification Approach for the Rating of Impact Factors." Technological Forecasting and Social Change 77, no. 1 (2010): 110-119.

Migrationpolicy.org. "Annual Number of New Asylum Applications in Select OECD Countries, 1980-2010.” Accessed September 9, 2018. https://www.migrationpolicy. org/programs/data-hub/humanitarian-protection-statistics.

Norris, Pippa. The Rise of the Radical Right: Voters and Parties in the Electoral Market. Cambridge: Cambridge University Press, 2005.

Özcan, Nihat Ali, and Özgür Özdamar. "Uneasy Neighbors: Turkish-Iranian Relations since the 1979 Islamic Revolution.” Middle East Policy 17 (2010): 101117.

Özçürümez, Saime, and Deniz Yetkin. "Limits to Regulating Irregular Migration in Turkey: What Constrains Public Policy and Why?" Turkish Studies 15, no. 3 (2014): 452-447.

Regina v. Appulonappa. 3 Supreme Court Record, 177, 2015. https://scc-csc.lexum. com/scc-csc/scc-csc/en/item/15648/index.do.

Regulation No. 1994/6169 on the Procedures and Principles related to Possible Population Movements and Aliens Arriving in Turkey either as Individuals or in Groups Wishing to Seek Asylum either from Turkey or Requesting Residence Permission in order to Seek Asylum From Another Country (Türkiyeye İltica eden veya başka bir ülkeye iltica etmek üzere Türkiyeden ikamet izni talep eden münferit yabancilar ile topluca siğinma amaciyla sinirlarimiza gelen yabancilara ve olabilecek nüfus hareketlerine uygulanacak usul ve esaslar hakkinda yönetmelik 94/6169). Unofficial UNHCR English translation. http://www. refworld.org/docid/49746cc62.html.

Reitz, Jeffrey G. "Canada: New Initiatives and Approaches to Immigration and Nation Building." In Controlling Immigration: A Global Perspective. 3rd ed., edited by James F. Hollifield et al., 88-116. Stanford, CA: Stanford University Press, 2014. 
Seawright, Jason, and John Gerring. "Case Selection Techniques in Case Study Research: A Menu of Qualitative and Quantitative Options." Political Research Quarterly 61, no. 2 (2008): 294-308.

Singh v. Ministry of Employment and Immigration. 1 Supreme Court Record, 177, 1985. http://scc-csc.lexum.com/scc-csc/scc-csc/en/item/39/index.do.

Sirkeci, Ibrahim, and Jeffrey H. Cohen. "Cultures of Migration and Conflict in Contemporary Human Mobility in Turkey.” European Review 24, no. 3 (2016): 381-396.

Standing Committee on Citizenship and Immigration, 35th Parliament, 2nd Session, Meeting No. 10, April 23, 1996. http://www.ourcommons.ca/Content/Archives/ Committee/352/cits/committee-e.html.

Suter, Brigitte. "Asylum and Migration Policy in Turkey: An Overview of Developments in the Field 1990-2013." Mim Working Paper Series, 2013. https://www.mah.se/upload/Forskningscentrum/MIM/Publications/WPS\%2013. 3\%20Brigitte\%20Suter\%20final.pdf.

Triandafyllidou, Anna. "Multi-Levelling and Externalizing Migration and Asylum: Lessons from the Southern European Islands." Island Studies Journal 9, no. 1 (2014): 7-22.

Turkey: Refoulement of Non-European Refugees - A Protection Crisis. AI Index: EUR 44/3/97. Amnesty International, 2000. https://www.amnesty.org/download/ Documents/160000/eur440311997en.pdf. 